by Maria Helena Henriques ${ }^{1}$, Ana Isabel A. S. S. Andrade ${ }^{2}$ and Fernando Carlos Lopes ${ }^{3}$

\title{
The Earth Sciences among the Community of Portuguese-Speaking countries and the future of Gondwana
}

\footnotetext{
${ }^{1}$ Departamento de Ciências da Terra, Faculdade de Ciências e Tecnologia da Universidade de Coimbra and Centro de Geociências da Universidade de Coimbra, Portugal. E-mail: hhenriq@dct.uc.pt

${ }^{2}$ Centro de Geofísica, da Universidade de Coimbra, Portugal.E-mail: aiandrade09@gmail.com

${ }^{3}$ Departamento de Ciências da Terra, Faculdade de Ciências e Tecnologia da Universidade de Coimbra and Centro de Geofísica da Universidade de Coimbra, Portugal.E-mail: fcarlos@dct.uc.pt
}

This paper aims to report impacts and changes regarding the Earth Sciences development among the CPLP - Community of Portuguese-Speaking Countries (Angola, Brazil, Cape Verde, East-Timor, Guiné-Bissau, Portugal, Mozambique and São Tomé and Príncipe), as a legacy of the International Year of Planet Earth (20072009). Extensive scientific literature has been produced in Portuguese during and after the triennium, namely as outputs of two important scientific events carried out in 2008 and 2012 at the University of Coimbra (Portugal). Those documents have been analysed and the results show a significant increase in the amount of researchers that have attended the events, in the affiliation institutions involved and in the produced publications. The kind of international cooperation represented within the analysed documents and the disciplines and territories that were under study also show increasing diversification and enlargement.

With approximately 280 million speakers, Portuguese is the fifth most spoken language in the world, and this work highlights the fact that communication facilities provided by a common language displays a key role in increasing scientific multilateral cooperation related to various fields of Earth Sciences within the CPLP, thus contributing to reduce imbalances in science and technology between the North and the South and to promote sustainable development.

\section{Introduction}

The Community of Portuguese-Speaking Countries (CPLP) was created in 1996 and it integrates 8 states (Republic of Angola, Federative Republic of Brazil, Republic of Cape Verde, Democratic Republic of East-Timor, Republic of Guiné-Bissau, Portuguese Republic, Republic of Mozambique and Democratic Republic of São
Tomé and Príncipe) scattered across 4 continents: Africa, America, Asia and Europe (Fig. 1).

Mainly located at the southern hemisphere, this discontinuous territory covers realities as diverse as Brazil, the world's fifth largest country by area, as the tiny archipelago of São Tomé and Principe, the smallest state of Africa in area (CPLP, 2012).

These eight fragments of former Gondwana correspond to $7.2 \%$ $\left(10,742000 \mathrm{~km}^{2}\right)$ of Earth's surface and are inhabited by more than 230 million of people sharing the same language and a common past. Besides the full and effective members, there are three observers associated: the Republic of Equatorial Guinea, the Republic of Mauritius and the Republic of Senegal. All three are located in Africa, but in only one the Portuguese is one of the official language, Equatorial Guinea.

Since its creation, the CPLP members are committed with several goals (CPLP, 1996), namely:

- To energize and deepen cooperation in the university field, in professional training and in different sectors of scientific and technological research with a view to increasing appreciation of its human and natural resources, and to promote and improve policies to staff training;

- To encourage bilateral and multilateral cooperation for the protection and preservation of the environment in the member countries with a view to promoting sustainable development.

In this context, during the implementation of the International Year of Planet Earth -IYPE (2007-2009), the Portuguese Committee, one of the three most successful IYPE Committees worldwide - it received the outstanding achievement Award during the Planet Earth Lisbon event in November 2009 (Woodfork and de Mulder, 2011) has launched several initiatives aiming at increasing the international cooperation within other National Committees (of Angola, Brazil, Cape Verde and Mozambique) acting on behalf of the Corporation at the national level (Mulder, 2008; Henriques et al., 2010).

Among them, special attention deserves the publication in Portuguese of the 12 Brochures of the IYPE, also available online, with the goal of making existing knowledge on Earth Sciences, frequently under-used, more available for the improvement of everyday life, especially in less developed countries (Mulder et al., 2006), a goal that is easier to achieve among people speaking the same language (Henriques et al., 2008a). So, 5,000 copies of the IYPE brochure in Portuguese were distributed in Portugal, Brazil, 


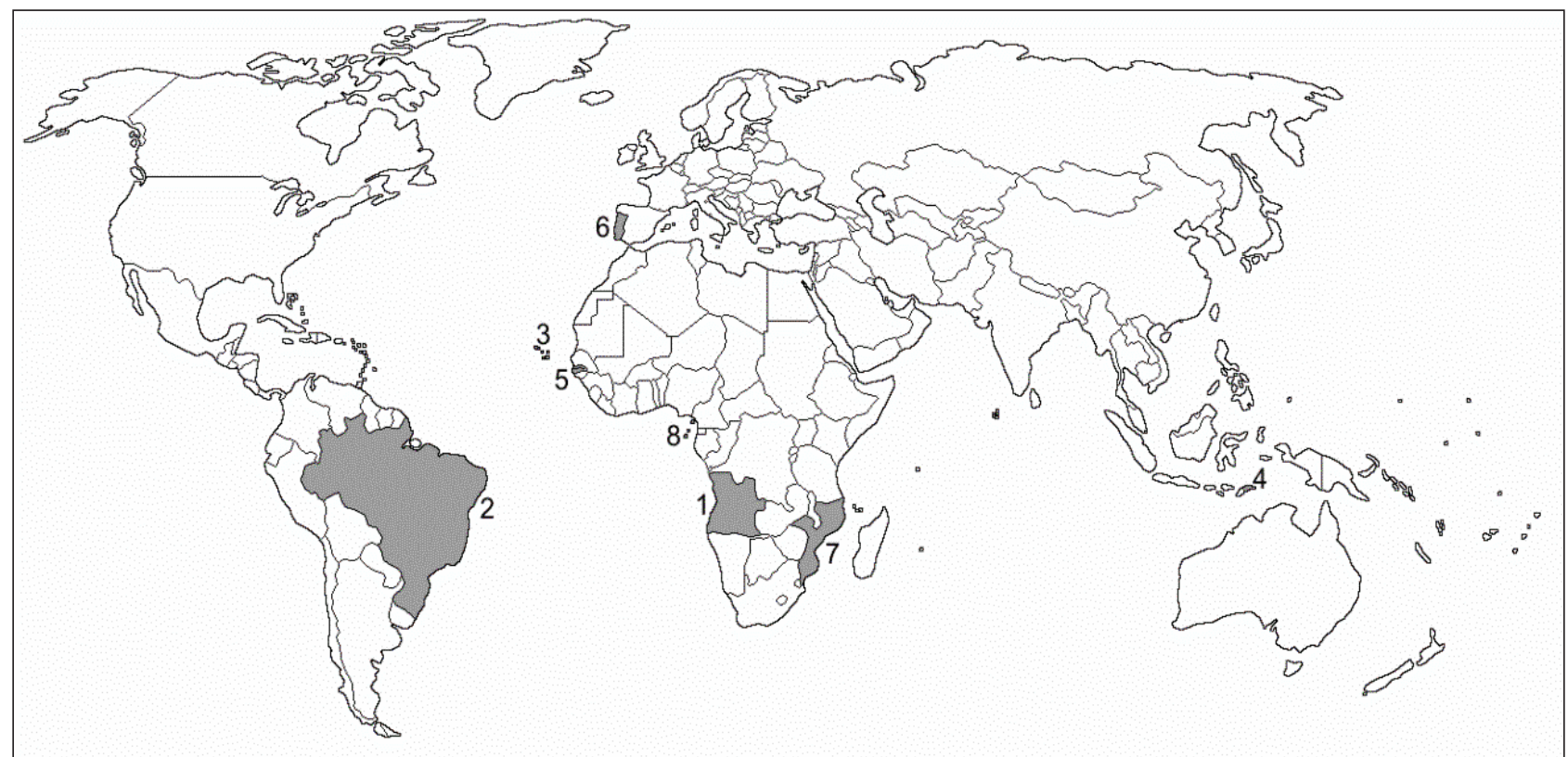

Figure 1. Geographic locations of the 8 states integrating the Community of Portuguese-Speaking Countries (CPLP). 1 - Republic of Angola; 2 - Federative Republic of Brazil; 3 - Republic of Cape Verde; 4 - Democratic Republic of East-Timor; 5 - Republic of Guiné-Bissau; 6 - Portuguese Republic; 7 - Republic of Mozambique; 8 - Democratic Republic of São Tomé and Príncipe.

Angola, Mozambique and Cape Verde and such brochures assisted significantly in the development of national IYPE programmes in those countries (Woodfork and de Mulder, 2011).

Portuguese is one of the official languages in several international organizations - the European Union, the Mercosur, the Union of South American Nations, the Organization of American States, the African Union and the Community of Portuguese-Speaking Countries. With approximately 280 million speakers, Portuguese is the fifth most spoken language in the world, the third most spoken language in the Western Hemisphere and the most widely spoken in the Southern Hemisphere of the Earth. However, Earth Sciences knowledge produced in Portuguese remains out of relevant organizations playing decisive roles in delivering "critical information to leading decision makers in the financial, legal, tax and accounting, healthcare, science and media markets" like the Thomson Reuters Company (2012), as English is considered the universal language of science, especially in the natural sciences (Testa, 2012). Such vision makes the task of bringing Earth Sciences to everyone, as intended by the IYPE (Mulder et al., 2006), a difficult endeavor. Moreover, being the IYPE a United Nations initiative implemented under the aim of the UNDESD - United Nations Decade of Education for Sustainable Development (20052014), one may ask how to promote the emergency of a new kind of education and research that benefits and reaches communities, as required by the UNDESD (UNESCO, 2012a), if the production, validation and diffusion of knowledge on Earth Sciences is conditioned by the idea that Portuguese, like many other languages, is not a language of science.

In the present work, major impacts and changes regarding the Earth Sciences development among the CPLP as a legacy of the International Year of Planet Earth (2007-2009) have been analysed. Data have been mainly collected from extensive literature following the organization of special events concerning recent advances on Earth Sciences among the CPLP countries, namely the First International Conference on the Development of Geosciences in the Community of Portuguese-Speaking Countries hold in 2008 (Henriques et al., 2008b), carried out during the IYPE triennium, and the First International Congress on Earth Sciences at the CPLP hold in 2012 (Henriques et al., 2012a, b; Lopes et al., 2012; Quinta-Ferreira et al., 2012), representing a legacy of the last one. Such documents were produced mainly in Portuguese thus contributing to: a better instinctive sympathy among the wider public for Earth scientists' work; a better integration of Earth System Science within curricula, and greater academic visibility of Earth Sciences within national education systems; and a deeper understanding about the potential of Earth Sciences for better planning decision making among politicians and public employees (Nield, 2005). Such goals correspond to achievements expected by the IYPE as a global initiative integrating the UNDESD (2005-2014), which calls for multiple perspective approach in the world of work as in the world of schools, based on the vision that "Understanding another person's or another group's point of view helps people, communities and nations to live more and work together to create a more sustainable future" (UNESCO, 2012b, p. 6).

By addressing local/global problems which Earth Sciences can contribute to mitigate, by involving different stakeholders from universities/schools, industry and politicians, and by valuing practices and knowledge embedded in local cultures, the events and documents here analysed reflect Earth Sciences advances among the CPLP and represent crucial contributions to make the Earth a safer, healthier and wealthier place for all the human beings as encouraged by UNESCO in the World Conference on Education for Sustainable Development, held in Bonn in 2009 (UNESCO, 2009). Moreover, they express ongoing concerns within the IUGS, on the need of contributing for the development of a scientific infrastructure for the Earth Sciences in Africa, where 5 of the 8 countries integrating the CPLP are located, through the IUGS-based project named "GEOERA: GEOscience Education Roadmap" (Martínez-Frías and Mogessie, 2012). 


\section{Major achievements on Earth Sciences among the Community of Portuguese- Speaking Countries}

The organization of the First International Conference on the Development of Geosciences in the Community of PortugueseSpeaking Countries, which was held in Coimbra (Portugal, in October 2008), represented an important milestone in the improvement of scientific cooperation among Earth scientists of the CPLP. The Coimbra Declaration then approved, welcoming the Maputo Declaration content on the Development of Geosciences in Africa approved in Maputo (Mozambique, 5th July 2006), the Luanda Declaration on the implementation of a mutual cooperation platform in the Community of Portuguese-Speaking Countries, in the field of environment, approved in Luanda (Angola, 24th April 2008), and the Arusha Declaration, approved in Arusha (Tanzania, 9th May 2008) during the launch of the International Year of Planet Earth (IYPE) in Africa, has committed all the participants with the need of studying their territories so that the partnerships in the CPLP can become stronger and productive (CD, 2008; Henriques, 2008). Four years later, the First International Congress on Earth Sciences at the CPLP, hold at the University of Coimbra (Portugal), reinforced such goals.

In this paper main developments on Earth Sciences among the CPLP are analysed, as a legacy of the Coimbra Declaration, i.e., of the IYPE, among researchers of Portuguese Language who, since 2008, have produced relevant information about their territories related to different disciplines within the Earth Sciences, usually unknown for speakers of other languages, and far away from ongoing transnational initiatives which fosters the expansion of Gondwana research in order "to include the subsequent history and destiny of the Gondwana fragments through today and beyond" (de Wit and Anderson, 2003, p. 369).

Data were collected from all kinds of documents produced during and as a consequence of the above mentioned scientific events (published articles and abstracts of poster and oral communications), and they were analyzed in order to address the following issues: how many researchers have attended both events; how many abstracts/ papers were produced; how many researchers have been involved in the produced publications and what is their provenance, i.e., the country where their host institution is located; what kind of international cooperation can we recognize; which territories and disciplines within the Earth Sciences have been under study.

\section{Events and participants}

The First International Conference on the Development of Geosciences in the Community of Portuguese-Speaking Countries was hold on the 13th and 14th October, 2008 at the University of Coimbra (Portugal), the oldest university of the CPLP, and included a post-congress fieldtrip to the Natural Park of Fogo Island, Republic of Cape Verde (Alfama et al., 2008; Fig. 2). A total of 164 participants attended the event, which included 3 conferences and 68 oral and poster communications globally representing the involvement of 241 persons, from 10 different countries, either individually or in teams (Fig. 3A). The presented work has been published as journal articles in a special volume of "Memórias e Notícias", the journal of Earth Sciences of the University of Coimbra (Henriques et al., 2008b).

The First International Congress on Earth Sciences at the CPLP

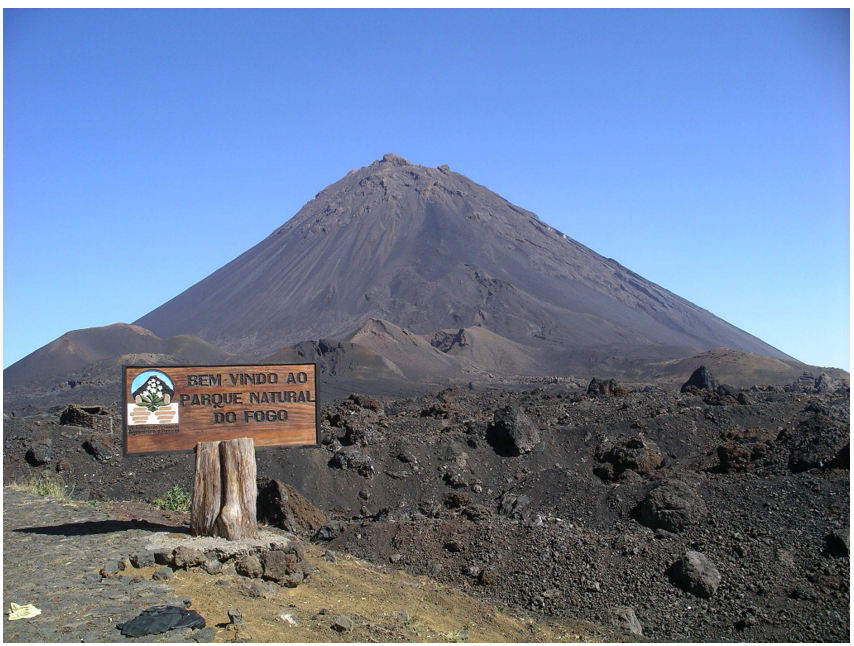

Figure 2 - The Natural Park of Fogo Island, Republic of Cape Verde, the destiny of a post-congress fieldtrip organized under the aim of the First International Conference on the Development of Geosciences in the Community of Portuguese-Speaking Countries, hold on the 13th and 14th October, 2008 at the University of Coimbra (Portugal).

was hold four years later, between the 12th and the 19th of May, 2012, celebrating 240 years of research and education on Earth Sciences among the CPLP, and it was also hold at the University of Coimbra (Portugal). It included a total of 8 pre and post-congress fieldtrips in Portugal, whose guides are available online (Andrade et al., 2012a, b). The event has been attended by 209 researchers, representing scientific work developed by a total of 921 persons affiliated to different institutions spread over 13 countries (Fig. 3B) and was reflected in 7 conferences/forums and 276 oral and poster communications. Besides the abstract book, also available online (Henriques et al., 2012a), the work there presented has been published as book chapters in 3 books edited by the University of Coimbra Academic Press (Henriques et al., 2012b; Lopes et al., 2012; QuintaFerreira et al., 2012).

\section{International cooperation}

The publications' authorship of the documents produced under the aim of the above mentioned events have also been analysed in order to characterize the kind of international cooperation that they represent. The 2008 Conference is dominated by national teams (Fig. 4A) mainly from Portugal (30) and Brazil (17), but international teams integrating Brazilian and Portuguese researchers represent an important feature to be considered (11); only 5 of the CPLP members have been then represented and there are 7 different kinds of international cooperation (with a total of 19 works).

Analysed data from the 2012 Congress display a quite different reality (Fig. 4B). Brazilian (142) and Portuguese teams (92) still dominate, now with Brazilian advantage, but a new network emerges reflecting a starting point regarding the international cooperation between Portuguese and Angolan researchers (16), aside with the persistence of the traditional cooperation between Portuguese and Brazilian Earth scientists (9). The involvement of researchers from the CPLP state-members has then increased up to 6 and the number of different kinds of international cooperation rose up to 15 (with a total of 44 works). Such results represent a starting point towards 


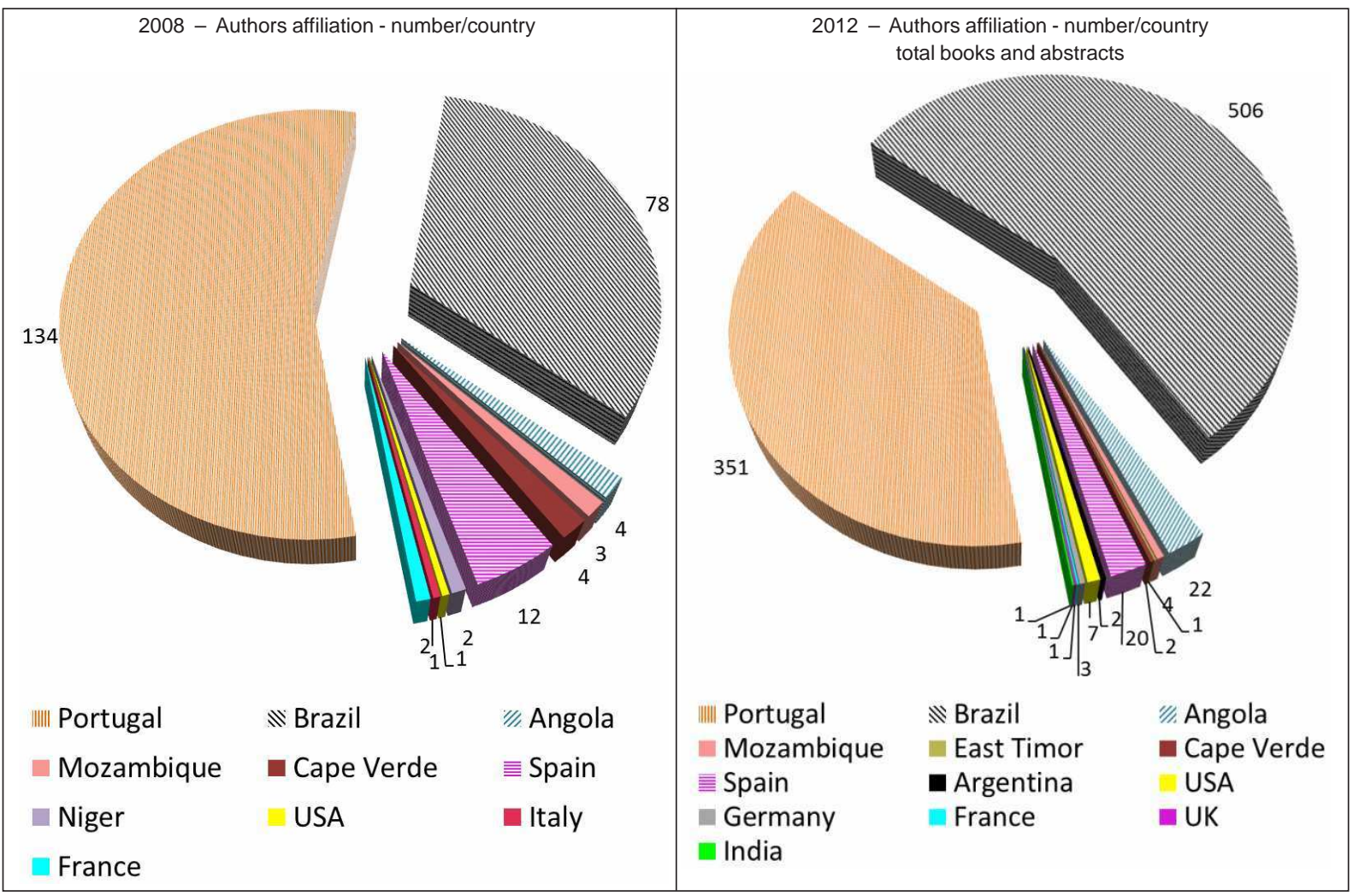

Figure 3. Total of participants and provenance countries attending the First International Conference on the Development of Geosciences in the Community of Portuguese-Speaking Countries hold in 2008 (A), and the First International Congress on Earth Sciences at the CPLP hold in 2012 (B).

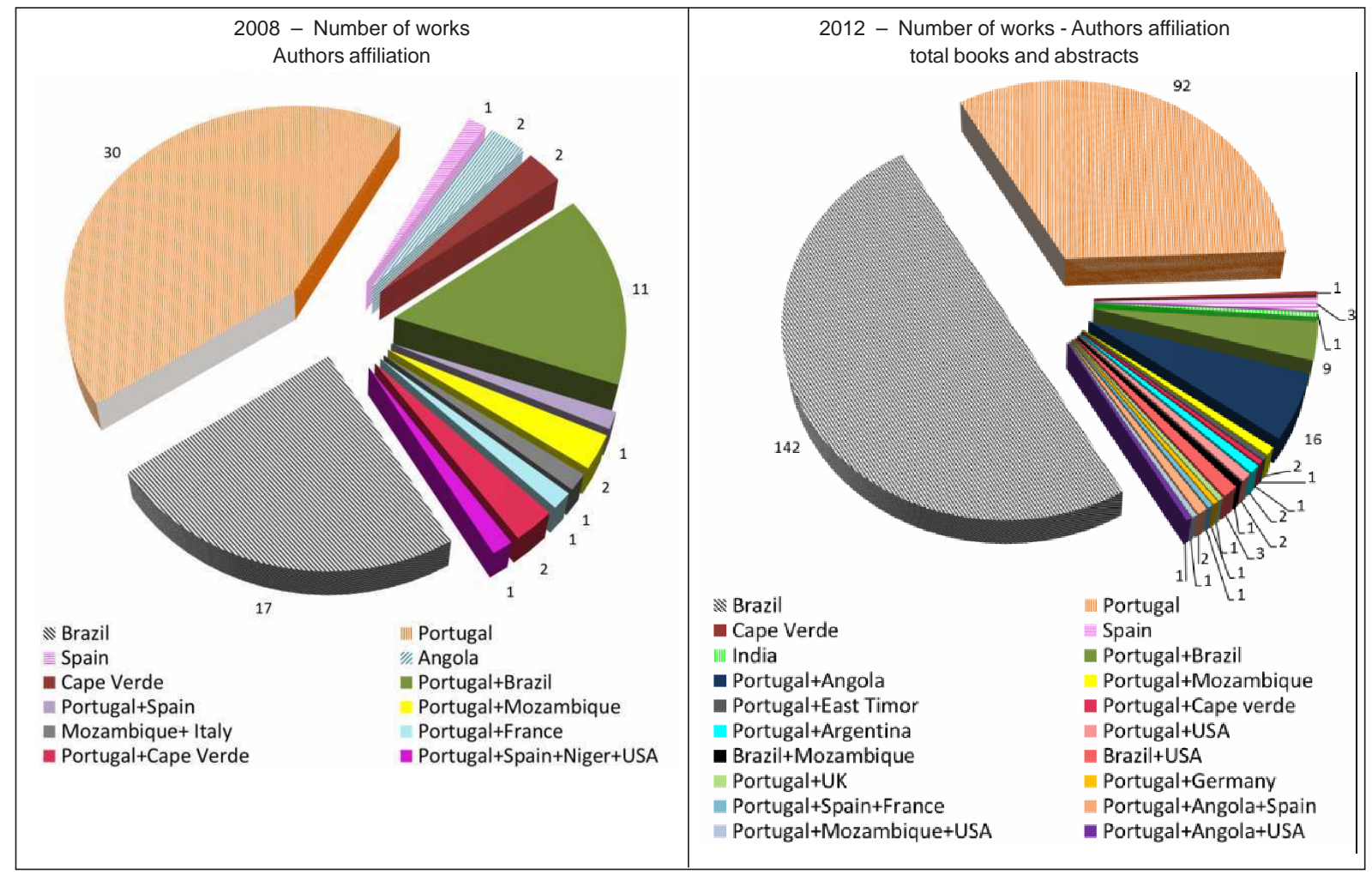

Figure 4. Publications' authorship of the documents produced under the aim of the First International Conference on the Development of Geosciences in the Community of Portuguese-Speaking Countries hold in 2008 (A), and the First International Congress on Earth Sciences at the CPLP hold in $2012(B)$. 
current statements considering that "Ideally, scientists from the developed world should consider their counterparts in the South as full and equal colleagues" (Schlueter and Davies, 2008, p. 8).

\section{Issues in focus}

Concerning the work produced in both events and their relations to the recognized disciplines within the Earth Sciences (i.e., Earth Sciences/Education, Earth Sciences History, Engineering Geology, Environmental Geology, Geoheritage/Geoconservation, Geological Hazards/Land Use Planning/Environment, Geomorphology/External Geodynamics, Geophysics, Geophysics and Geochemical Prospection, Hydrogeology, Marine/Coastal geology, Mineral and Energetic resources, Mineralogy/Petrology/Geochemistry, Museums, in 2012, not represented in Fig. 7), and a few contributions related to other territories outside the CPLP (Antarctic, Argentina, Cameroon, Columbia, Gabon, Germany, Malawi, Morocco, Niger, Spain, Uruguay, Sudan, Thailand, Venezuela) or even outside the Earth (Mars, Venus, Titan), most of the works presented in both events refer to different locations/subjects in Portugal, Brazil, Angola, Mozambique, Cape Verde and São Tomé and Príncipe in 2008, either alone or in comparison among them or with other territories (Fig. 7A), enlarged to Guiné-Bissau and East Timor in 2012 (Fig. 7B). Again, Portugal and Brazil have been the most focused territories, with a significant predominance of Brazil in 2012. Angola records an important increase in 2012, reflecting the international cooperation previously emphasized as a result of the partnership between the University of Coimbra (Portugal) and the Private University of
Paleontology, Planetary Sciences, Sedimentology/Stratigraphy, Structural Geology/Tectonics, Technology applied to Earth Sciences), the results show great diversity of interest and a relative balance in its distribution in 2008, which has been reinforced in 2012 (Figs. 5A and 5B). Moreover, disciplines like Planetary Sciences, Sedimentology/Stratigraphy, Hydrogeology, Geomorphology/ External Geodynamics, Environmental Geology, Geophysics and Geochemical Prospection, Engineering Geology and Structural Geology/ Tectonics, which were absent or scarcely focused in the 2008 event, were the subject of a greater interest in the 2012 event; research on Mineralogy/Petrology/Geochemistry and Geological Hazards/Land Use Planning/Environment has also recorded a significant increase.

Earth Sciences Education has displayed an important role in both events, whether strictly considered in its formal dimension and/or through non-formal approaches, i.e. considering museums as educational resources and geoconservation (and their products, e.g., geoparks) as an emerging geoscience particularly relevant in the promotion of education for sustainable development (Henriques et al., 2011; Henriques et al., $2012 \mathrm{c}$ ); in the broadest sense it involved $40.8 \%$ and $26.5 \%$ of the works, in 2008 and 2012, respectively (Figs. 6A and 6B).

\section{Territories under study}

Despite general issues not assigned to any particular place on Earth ( 3 works in 2008 and 20 works

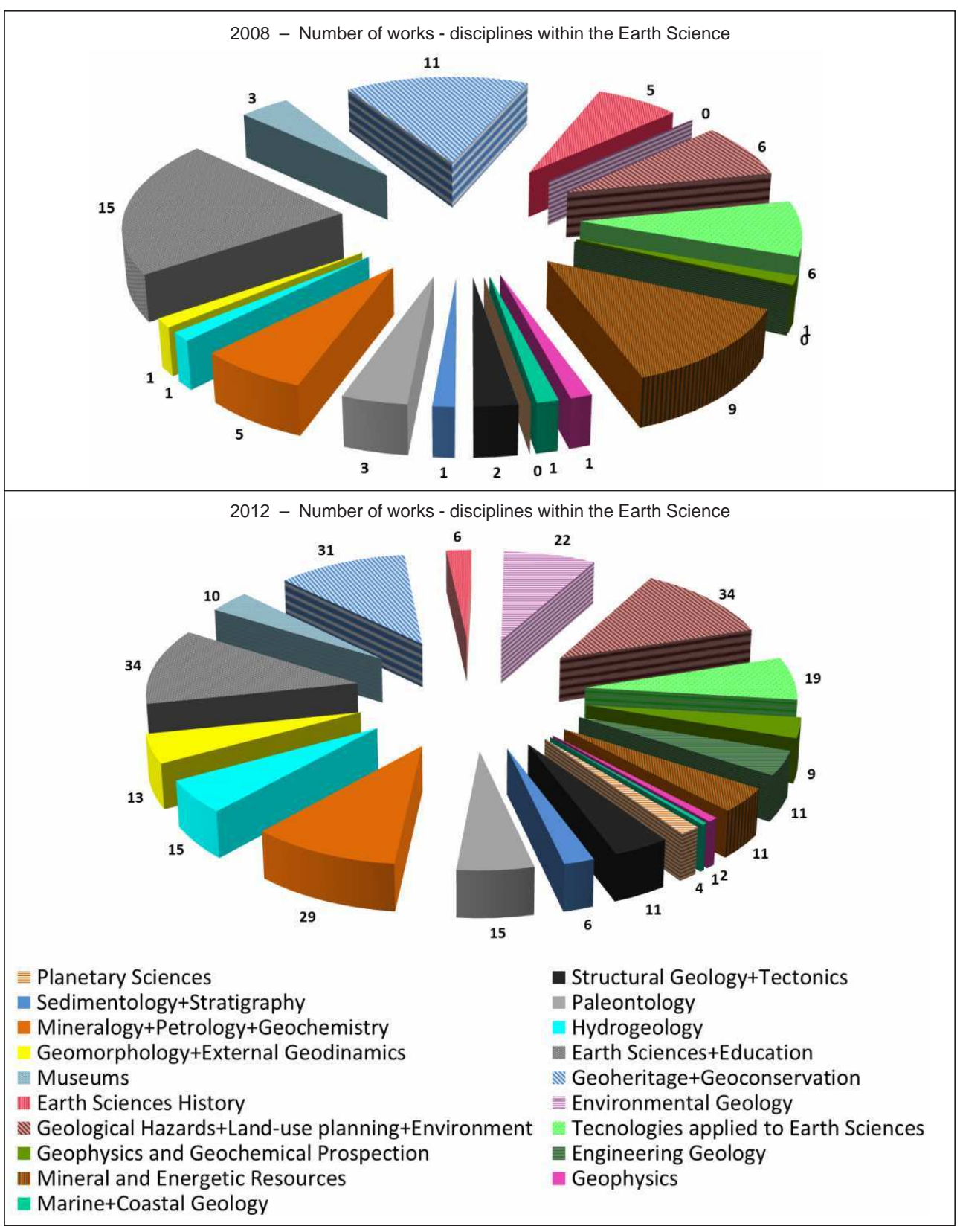

Figure 5 - Total of works per disciplines within the Earth Sciences focused at the First International Conference on the Development of Geosciences in the Community of Portuguese-Speaking Countries hold in 2008 (A), and at the First International Congress on Earth Sciences at the CPLP hold in $2012(B)$. 


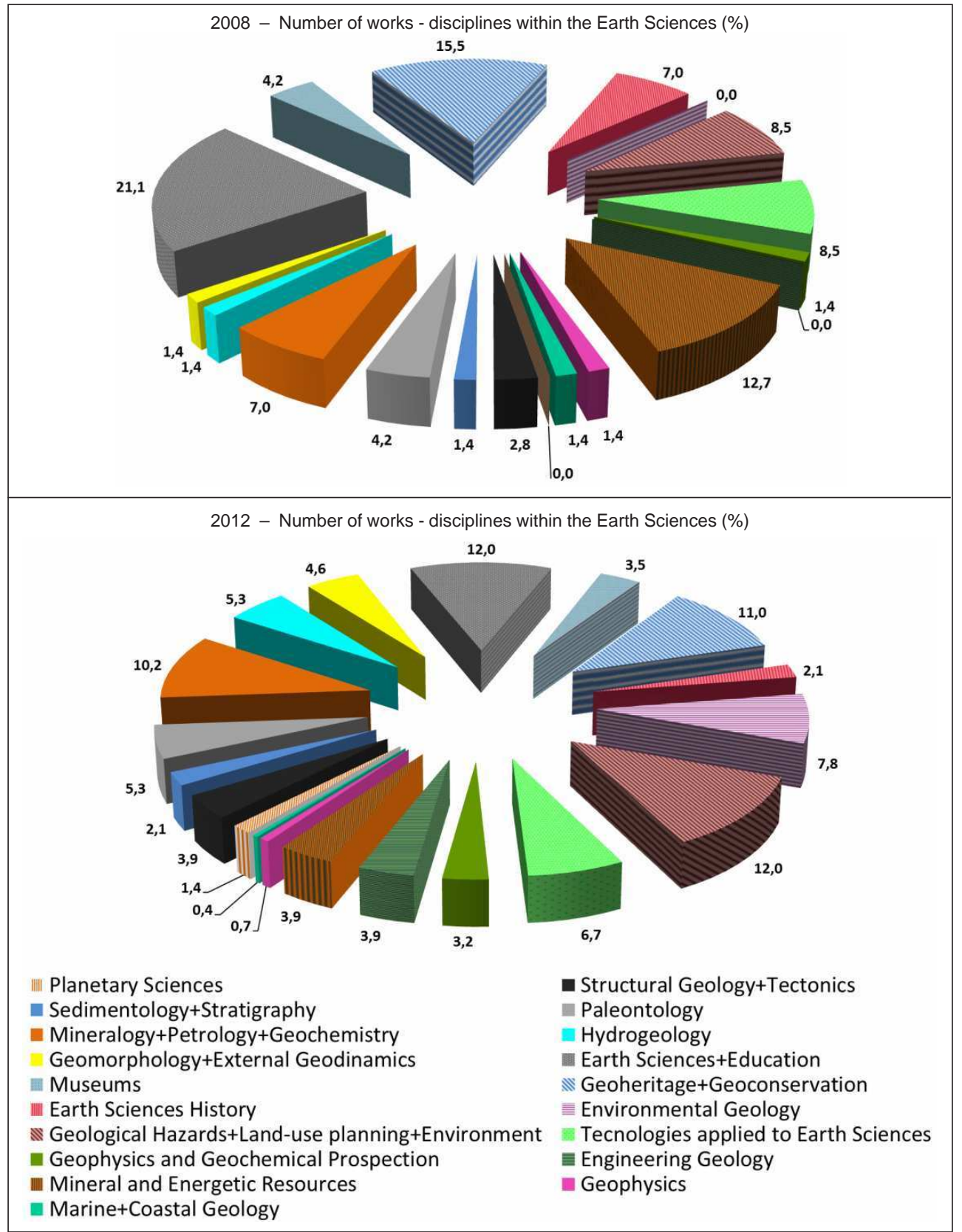

Figure 6 - Total of works per disciplines, in percentage, within the Earth Sciences focused at the First International Conference on the Development of Geosciences in the Community of PortugueseSpeaking Countries hold in 2008 (A), and at the First International Congress on Earth Sciences at the CPLP hold in 2012 (B).

Lubango (Angola); 11 papers were produced and published in Henriques et al. (2012b), Lopes et al. (2012) and Quinta-Ferreira et al. (2012), most of them based on MsC thesis approved at the University of Coimbra during the last years.

\section{Conclusions and implications}

The International Year of Planet Earth (2007-2009) represented a major opportunity for the 5 IYPE National Committees integrating the CPLP to launch a new era of intense scientific bilateral and multilateral cooperation related to various fields of Earth Sciences with a view to promoting sustainable development by mobilizing the communication facilities that a common language may provide.
Three of the 5 IYPE National Committees of the CPLP represent African states (Angola, Cape Verde and Mozambique), with scarce or lacking participation in documents stating their contribution to the African legacy for the IYPE (e.g., Toteu, 2010) and/or in relevant subsequent international initiatives, as the "African Alive Corridors" (Toteu et al., 2010). However, Earth Sciences has recorded a strong development among them, and this paper intends to present the major achievements in research and educational activities among the CPLP as a result of several networks established under the aim of the IYPE and as a legacy of such United Nations initiative, launched at the University of Coimbra. They reflect contributions to be taken into account in the context of current discussions about the present and the future of Africa, of former Gondwana, and the Earth itself, namely regarding the need of reducing imbalances in science and technology between the North and the South (UNESCO, 2005).

The analysis of several scientific documents, published under the aim of the organization of two international congresses (2008 and 2012) involving researchers affiliated to different scientific institutions located mainly within the CPLP, and supported by a wide number of partners (from police makers to private companies), allows the recognition of important achievements on Earth Sciences within that community.

The results show a significant increase in the number of researchers involved in work preparation/ presentation in the events (241 in 2008 and 921 in 2012), and affiliated to a large number of countries inside and outside the CPLP (10 in 2008 and 13 in 2012). Moreover, although Brazilian and Portuguese researchers, individually, integrating national teams, or under the aim of bilateral actions, dominate the scenario, in 2012 new networks have arisen, enlarging it to Angolan researchers, mainly composed of young people who have developed postgraduate studies at the University of Coimbra in the last four years, as a result of a partnership established in 2008 with the Private University of Angola at Lubango (Rodrigues et al., 2012). Such fact represents an important support for on-going initiatives addressing the need of intensifying geo-education actions within the African continent (Martínez-Frías and Mogessie, 2012). Almost all the main disciplines within the Earth Sciences have been approached in both events, with particular emphasis on different Earth Sciences Education issues, but 


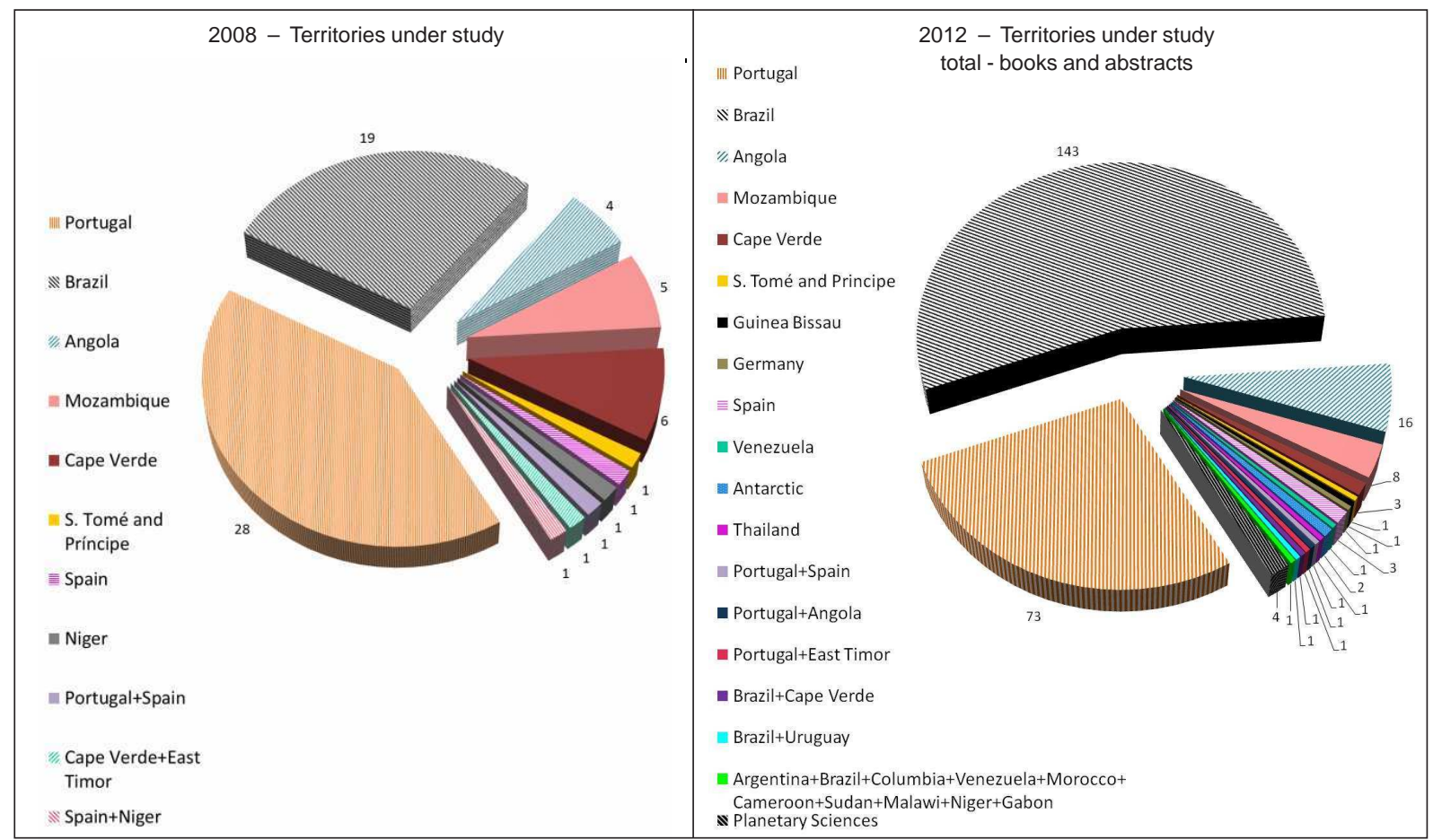

Figure 7 - Territories under study at the First International Conference on the Development of Geosciences in the Community of Portuguese-Speaking Countries hold in 2008 (A), and at the First International Congress on Earth Sciences at the CPLP hold in $2012(B)$.

diversification in 2012 has strongly increased. Finally, most of the territories of the CPLP have been subject of interest in 2008, and all of them, representing 8 fragments of former Gondwana, have been handled in 2012.

Promoting sustainable development calls for different requirements, namely for actions safeguarding linguistic diversity, as pointed by the UNESCO (2005), that considers globalization as a major challenge to cultural diversity, "due to the increasing commercialization of cultural demand" (op. cit., p. 34). Science communication is an essential component of development strategies as "The biggest single factor determining any country's potential for achieving sustainable social and economic growth - and particularly, in the case of developing countries, of attaining the Millennium Development Goals - is its ability to access and apply the fruits of modern science and technology in a responsible manner" (Dickson, 2012). Such views are clearly divergent of current perspectives that assign to one language - the English - the status of exclusive vehicle for communicating science, including Earth Sciences, thus contributing to the non-integration of researchers and know-how of other native languages and regions "as international journals rarely accept papers dealing with local problems" (Schlueter and Davie, 2008, p. 5).

First researchers of Gondwana were brave Portuguese navigators who, from the fifteenth century onwards began, empirically, to write in Portuguese the first chapters of Gondwana biography. Since the nineteen century, and like Gondwana, the Portuguese Empire has broken up into 8 fragments, presently represented by 8 independent states scattered across four continents. But the same language - the fifth most spoken language in the world -, and a common past still unites what the dynamics of the Earth has drifted. It is now time to take advantage on the common language to promote common concerns focused on the future of former Gondwana.

\section{Acknowledgements}

This work is a contribution for the UNESCO's International Geoscience Programme, namely for the on-going UNESCO's Earth Science Education Initiative in Africa.

\section{References}

Alfama, V., Gomes, A.M. and Brilha, J., 2008, Guia Geoturístico da Ilha do Fogo, Departamento de Ciências da Terra da Faculdade de Ciências e Tecnologia da Universidade de Coimbra, 64 p.

Andrade, P.S., Quinta Ferreira, M. and Lopes, F.C., coord., 2012a, Excursões Científicas: I Congresso Internacional Geociências na CPLP - 240 anos de Geociências na CPLP, Coimbra, 12 a 19 de Maio de 2012, Centro de Geociências e Centro de Geofísica da Universidade de Coimbra, v. 1, 36 p. (ISBN: 978-972-95640-9-3/978-989-97823-1-0). Online: http:// www.uc.pt/congressos/GeoCPLP2012/Programa/LivrosExcursoes/> (retrieved March 2013)

Andrade, P.S., Quinta Ferreira, M. and Lopes, F.C., coord., 2012b, Excursões Científicas: I Congresso Internacional Geociências na CPLP - 240 anos de Geociências na CPLP, Coimbra, 12 a 19 de Maio de 2012, Centro de Geociências e Centro de Geofísica da Universidade de Coimbra, v. 2, 129 p. (ISBN: 978-972-95640-9-3/978-989-97823-1-0). Online: http:// www.uc.pt/congressos/GeoCPLP2012/Programa/LivrosExcursoes/> (retrieved March 2013).

CD, 2008, Coimbra Declaration on the Development of Geosciences in the Community of Portuguese Speaking Countries (CPLP): Year of Planet Earth. <http://yearofplanetearth.org/content/downloads/portugal/ CoimbraDeclaration.pdf> (retrieved March 2013).

CPLP, 1996, Declaração Constitutiva da Comunidade dos Países de Língua Portuguesa - CPLP, Comunidade dos Países de Língua Portuguesa. Online: <http://www.cplp.org/Default.aspx?ID=252 > (retrieved March 2013).

CPLP, 2012, Estados Membros. Comunidade dos Países de Língua Portuguesa. <http://www.cplp.org/id-22.aspx> (retrieved March 2013). 
de Wit, M.J. and Anderson, J.M., 2003, Gondwana Alive Corridors: Extending Gondwana Research to Incorporate Stemming the Sixth Extinction, Gondwana Research, v. 6, n 3, pp. 369-408.

Dickson, D., 2012, Science communication: an essential component of development strategies. The UNESCO Courier - 14.03.2012 <http:// www.unesco.org/new/en/unesco-courier/single-view/news/ science_communication_and_responsibility/ > (retrieved March 2013).

Henriques, M. H., 2008, Declaração de Coimbra sobre o Desenvolvimento das Geociências na Comunidade dos Países de Língua Portuguesa in Henriques, M.H., Lopes, F.C., Catarino, L., Duarte, L.V., Rodrigues, N. and Andrade, A.I., eds., Conferência Internacional As Geociências no Desenvolvimento das Comunidades Lusófonas: Memórias e Notícias, $\mathrm{n}^{\circ}$ 3 (Nova Série), pp. 539-542.

Henriques, M. H., Guimarães, F. A., Ribeiro, A., Sá, A., Moura, D., Silva, E., Brilha, J., Galhardo, M., Cachão, M. and Ramalho, M., 2008a, O Ano Internacional do Planeta Terra em Portugal, in Henriques, M.H., Lopes, F.C., Catarino, L., Duarte, L.V., Rodrigues, N. and Andrade, A.I., eds., Conferência Internacional As Geociências no Desenvolvimento das Comunidades Lusófonas: Memórias e Notícias, $n^{\circ} 3$ (Nova Série), pp. 85- 92.

Henriques, M.H., Lopes, F.C., Catarino, L., Duarte, L.V., Rodrigues, N. and Andrade, A.I. eds., 2008b, As Geociências no Desenvolvimento das Comunidades Lusófonas, Memórias e Notícias, Coimbra, $n^{\circ} 3$ (Nova Série), 547 p. (ISSN 0870-0397).

Henriques, M.H., Guimarães, F.A., Sá, A.A., Silva, E. and Brilha, J., 2010, The International Year of Planet Earth in Portugal: past activities and further developments: Episodes, v. 33, nº 1, pp. 33-37.

Henriques, M.H., Pena dos Reis, R. Brilha, J. and Mota, T.S., 2011, Geoconservation as an emerging geosciences: Geoheritage, v. 3, no. 2, pp. 117-128.

Henriques, M.H., Andrade, A.I., Lopes, F.C., Pena dos Reis, R. and Quinta Ferreira, M., Barata, M.T., coord., 2012a, Livro de Resumos do I Congresso Internacional Geociências na CPLP - 240 anos de Geociências na CPLP. Coimbra 12 a 19 de Maio de 2012, Centro de Geociências e Centro de Geofísica da Universidade de Coimbra eds., 331 p. (ISBN: 978-972-95640-8-6/978-989-97823-0-3). Online: http://www.uc.pt/ congressos/GeoCPLP2012/Programa/LivroDeResumos/> (retrieved March 2013)

Henriques, M.H., Andrade, A.I., Quinta Ferreira, M., Lopes, F.C., Barata, M.T., Pena dos Reis, R. and Machado, A., coord., 2012b, Para aprender com a Terra. Memórias e Notícias de Geociências no Espaço Lusófono, Imprensa da Universidade de Coimbra/Coimbra Academic Press, 424 p. (ISBN: 978-989-26-0524-1).

Henriques, M.H., Tomaz, C. and Sá, A.A., 2012c, The Arouca Geopark (Portugal) as an educational resource: a study case: Episodes, v. 35, $\mathrm{n}^{\circ} 4$, pp. 481-488.

Lopes, F.C., Andrade, A.I., Henriques, M.H., Quinta-Ferreira, M., Barata, M.T. and Pena dos Reis, R., coord., 2012, Para Conhecer a Terra: Memórias e Notícias de Geociências no Espaço Lusófono, Imprensa da Universidade de Coimbra/Coimbra Academic Press, 502 p. (ISBN: 978989-26-0511-1).

Martínez-Frías, J. and Mogessie, A., 2012, The need for a geoscience education roadmap for Africa: Episodes, v. 35, $\mathrm{n}^{\circ}$ 4, pp. 489-492.

Mulder, E., 2008, A global campaign, in Derbyshire, E., ed, The official publication of the International Year of Planet Earth, UNESCO/IUGS:
Boston Hannah International, pp. 30-35.

Mulder, E.F.J., De Nield, T. and Derbyshire, E., 2006, The International Year of Planet Earth (2007-2009): Earth Sciences for Society: Episodes, v. 29, no.2, pp. 82-86.

Nield, T., 2005, Outreach - bringing Earth sciences to everyone, Earth Sciences for Society Foundation, Leiden, $16 \mathrm{p} .<\mathrm{http}: / / \mathrm{www}$.yearofplanetearth.org/ content/downloads/Outreach.pdf > (retrieved March 2013).

Quinta-Ferreira, M., Barata, M.T., Lopes, F.C., Andrade, A.I., Henriques, M.H., Pena dos Reis, R. and Alves, I., coord. eds., 2012, Para desenvolver a Terra: Memórias e Notícias de Geociências no Espaço Lusófono, Imprensa da Universidade de Coimbra/Coimbra Academic Press, 530 p. (ISBN: 978-989-26-0531-9).

Rodrigues, N., Pereira, A., Ribeiro, C. and Ventura, M., 2012, A parceria entre a UPRA-Lubango e o DCT/FCTUC - Rescaldo de quatro anos de colaboração na área das geociências, in Henriques, M.H., Andrade, A.I., Lopes, F.C., Pena dos Reis, R., Quinta Ferreira, M., Barata, M.T., coord. eds., 2012a, Livro de Resumos do I Congresso Internacional Geociências na CPLP - 240 anos de Geociências na CPLP, Coimbra 12 a 19 de Maio de 2012, Centro de Geociências e Centro de Geofísica da Universidade de Coimbra, eds., p. 270 (ISBN: 978-972-95640-8-6/978-989-97823-03). Online: http://www.uc.pt/congressos/GeoCPLP2012/Programa/ LivroDeResumos/ > (retrieved March 2013).

Schlueter, T. and Davie, T.C., 2008, What future for geo-education in Africa?: A World of Science, Natural Sciences Quarterly Newsletter, UNESCO Natural Sciences Sector, v. 6, $\mathrm{n}^{\circ} 2$, pp. 2-8.

Testa, J., 2012, The Thomson Reuters Journal Selection Process. Thomson Reuters Science. <http://thomsonreuters.com/products_services/science/ free/essays/journal_selection_process/ > (retrieved March 2013).

Thomson Reuters Company, 2012, About us. Thomson Reuters. <http:// thomsonreuters.com/about/> (retrieved March 2013).

Toteu, S.F., 2010, Africa and the International Year of Planet Earth (IYPE): Promoting Earth sciences-based decision making in Africa: Journal of African Earth Sciences, v. 58, pp. 605-607.

Toteu, S.F., Anderson, J.M. and de Wit, M., 2010, Africa alive Corridors: Forging a new future for the people of Africa by the people of Africa: Journal of African Earth Sciences, v. 58, pp. 692-715.

UNESCO, 2005, UNESCO and Sustainable Development. UNESCO, Paris, $42 \mathrm{p}$.

UNESCO, 2009, Bonn Declaration. UNESCO World Conference on Education for Sustainable Development, $6 \mathrm{p}$.

<http://unesdoc.unesco.org/images/0018/001887/188799e.pdf > (retrieved March 2013).

UNESCO, 2012a, Shaping the Education of Tomorrow. 2012 Report on the UN Decade of Education for Sustainable Development, Abridged, UNESCO, Paris, $89 \mathrm{p}$.

<http://unesdoc.unesco.org/images/0021/002166/216606e.pdf > (retrieved March 2013).

UNESCO, 2012b, Exploring Sustainable Development: A MultiplePerspective Approach. Education for Sustainable Development in Action. Learning \& Training Tools $N^{\circ} 3$ - 2012. UNESCO Education Sector, Paris, 35 p. 〈http://unesdoc.unesco.org/images/0021/002154/215431E.pdf > (retrieved March 2013).

Woodfork, L. and de Mulder, E., 2011, International Year of Planet Earth. Final Report. UNESCO-IUGS, 80 p. < http://www.yearofplanetearth.org/ content/downloads/IYPE-FinalReport.pdf > (retrieved March 2013). 